SUPPLEMENTARY MATERIAL

\title{
Aporphine alkaloid contents increase with moderate nitrogen supply in Annona diversifolia Saff. (Annonaceae) seedlings during diurnal periods
}

José Agustín Orozco-Castillo ${ }^{\mathrm{a}, \mathrm{b}}$; Rocío Cruz-Ortega ${ }^{\mathrm{c}}$; Mariano MartinezVázquez ${ }^{\mathrm{d}}$ and Alma Rosa González-Esquinca ${ }^{\mathrm{a}^{*}}$

${ }^{a}$ Laboratorio de Fisiología y Química Vegetal, Instituto de Ciencias Biológicas, Universidad de Ciencias y Artes de Chiapas, LibramientoNortePoniente1150, col. Lajas

Maciel C.P. 29039, Tuxtla Gutiérrez, Chiapas, México; ${ }^{b}$ Posgrado en Ciencias Biológicas, Universidad Nacional Autónoma de México;Av. Ciudad Universitaria 3000, C.P. 04510, Coyoacán, Distrito Federal, México; ${ }^{C}$ Instituto de Ecología, Universidad Nacional Autónoma de México; Circuito Exterior s/n, Apartado Postal 70-275, Ciudad Universitaria. Delegación Coyoacán, C.P. 04510, Distrito Federal, México; ${ }^{d}$ Instituto de Química, Universidad Nacional Autónoma de México; Circuito Exterior s/n, Ciudad Universitaria. Delegación Coyoacán, C.P. 04510, Distrito Federal, México

*Email: aesquinca@unicach.mx 


\title{
Aporphine alkaloid contents increase with moderate nitrogen supply in Annona diversifolia Saff. (Annonaceae) seedlings during diurnal periods
}

\begin{abstract}
Aporphine alkaloids are secondary metabolites that are obtained in low levels contents from species of the Annonaceae family. Nitrogen addition may increase the alkaloid content in plants. However, previous studies published did not consider that nitrogen could change the alkaloid content throughout the day. We conducted this short-term study to determine the effects of nitrogen applied throughout the diurnal period on the aporphine alkaloids via measurements conducted on the roots, stems and leaves of $A$. diversifolia seedlings. The 60-day-old seedlings were cultured with the addition of three levels of nitrogen $(0,30$ and $60 \mathrm{mM})$, and alkaloid extracts were analysed using high-performance liquid chromatography. The highest total alkaloid content was measured in the treatment with moderate nitrogen supply. Further, the levels of aporphine alkaloids changed significantly in the first few hours of the diurnal period. We conclude that aporphine alkaloid content increased with moderate nitrogen supply and exhibited diurnal variation.
\end{abstract}

Keywords: Liriodenine; Atherospermidine; Lysicamine; Diurnal variation; Hydroponic 


\section{Experimental}

\subsection{Plant material and growth conditions}

A. diversifolia Saff. Seedlings were obtained from seeds (500) germinated in a growth chamber (Conviron® CMP4030), using a paper sheet technique (Ministerio de Agricultura 1976).

The seedlings with cotyledonary leaves (10 days, $n=320)$ were grown in hydroponic culture using distilled water ( $\mathrm{pH} 6.91 \pm 0.07$ ) until they achieved three true leaves (60 days). These seedlings were grown in a growth chamber (Conviron® CMP4030) under controlled conditions (relative humidity $70-80 \%$; and temperature $30 \pm 2{ }^{\circ} \mathrm{C}$ ) and a 12 -h photoperiod for which the light $\left(24.42 \pm 10.51 \mu \mathrm{mol} \mathrm{m}^{2} \mathrm{~S}^{-1}\right)$ was generated using Sylvania® Octron T8 lamps and measured using a LI-COR $®$ LI-250 light metre. These seedlings were used in the nitrogen supply test.

\subsection{Nitrogen treatment test}

The nitrogen supply tests were performed under controlled conditions using hydroponic culture in a growth chamber (see plant material and growth conditions). Three treatments with zero, moderate and high nitrogen supply (0,30 and $60 \mathrm{mM} \mathrm{N}$, respectively) were tested using Murashige and Skoog nutrient solutions (Table S1). The $60 \mathrm{mM} \mathrm{N}$ treatment was used for reference (Murashige \& Skoog 1962) and the 0 and $30 \mathrm{mM} \mathrm{N}$ treatments were modified Murashige and Skoog media. The decrease in potassium from the use of $\mathrm{KNO}_{3}$ in the modified 0 and $30 \mathrm{mM}$ solutions was proportionately offset using $\mathrm{KOH}$. The $\mathrm{pH}$ of each nutrient solution was adjusted to 6.0. The A. diversifolia Saff. seedlings (320) were fertilised with $15 \mathrm{~L}$ of nutrient solution. The seedlings were maintained under these conditions for $0,2,4,6,8,12$ or $24 \mathrm{~h}(0 \mathrm{~h}$ corresponding to a 7:00 am), and five samples were harvested at the end of each time period. The nutrient solution was monitored at each sampling period using a conductivity metre (YSI Incorporated® 85) and potentiometer (Thermo Scientific ${ }^{\circledR}$ Orion 3-Star). The harvested plant material was dissected from roots, stem and leaves, and then dried at room temperature for alkaloid extraction. The experiment was performed using three replicates.

\subsection{Alkaloids extraction and determination}


The alkaloid extracts from different organs were obtained from seedlings sample $(n=5)$. The dried and powdered samples $(n=5)$ were moistened with a saturated solution of $\mathrm{Na}_{2} \mathrm{CO}_{3}$ for $48 \mathrm{~h}$ and then allowed to dry at shade at room temperature $\left(26 \pm 2.5^{\circ} \mathrm{C}, 55.5 \pm 12\right.$ $\left.\mu \mathrm{M} . \mathrm{m}^{-2} . \mathrm{s}^{-1}, 64.55 \pm 9.8 \% \mathrm{RH}\right)$ for $48 \mathrm{~h}$. The total alkaloid extraction was performed following De la Cruz and González-Esquinca (2012).

Due to the low yield of alkaloids in seedlings, the plant roots of adult A. diversifolia (1495 g) were used to obtain and determine the structure of two of the alkaloids, and the third alkaloid, lysicamine, was donated by Dr Diego Cortes. The roots were collected from Ursulo Galvan Chiapas, México in August 2010. The plant material was allowed to dry at shade at room temperature $\left(26 \pm 2.5^{\circ} \mathrm{C}, 55.5 \pm 12 \mu \mathrm{M} \cdot \mathrm{m}^{-2} . \mathrm{s}^{-1}, 64.55 \pm 9.8 \% \mathrm{RH}\right)$ for $48 \mathrm{~h}$. The roots dried was powdered and then defatted for $24 \mathrm{~h}$ using hexane. Total alkaloid extraction was performed following De la Cruz and González-Esquinca (2012). Total alkaloids (2.2698 g) were obtained from dried and powered roots. Liriodenine was obtained in solid yellow precipitate form. Specifically, the liriodenine was purified using filtration and then successive crystallization with $\mathrm{CHCl}_{3}$ to obtain yellow needles (1.1698 g); m.p. 280$282^{\circ} \mathrm{C}$; UV $\lambda \max 248,272,310,414 ;{ }^{1} \mathrm{H} \mathrm{NMR}\left(\mathrm{CDCl}_{3}, 300 \mathrm{MHz}\right): \delta 8.90(\mathrm{~d}, \mathrm{~J}=5.4 \mathrm{~Hz}$, H5), $\delta 8.66$ (dt, J=7.95 Hz, H11), $\delta 8.59$ (dd, J=7.95, 0.9 Hz, H8), $\delta 7.79$ (d, J=5.19 Hz, H4), $\delta 7.58$ (dt, J=7.8, 0.9 Hz, H10), $\delta 7.52$ (dt, 7.94, 1.22 Hz, H9), $\delta 7.20$ (s, H3), $\delta 6.39$ (s, $2 \mathrm{H})$.

Other aporphine alkaloids were obtained from the remaining extract $(1.1 \mathrm{~g})$ using a chromatographic column packed with silica gel 60 HF254 (Merck, $2 \times 40 \mathrm{~cm}$ of 0.063-0.2 $\mathrm{mm})$. The column was eluted stepwise using an eluent system comprised of $n$ hexane:ethylacetate:methanol of increasing polarity. During the elution procedure, 471 fractions of $100-\mathrm{mL}$ each were obtained. The presence of alkaloids in the fractions during the column elution was monitored using thin-layer chromatography and Dragendorff reagent. An alkaloid mixture (120 mg) was obtained from fractions 148-321 (nhexane:ethyl acetate 5:5, 3:7). The alkaloid mixture was separated using thinlayer chromatography plates (Sigma-Aldrich, aluminium foil backing, $20 \times 20 \mathrm{~cm} ; 25 \mathrm{~mm}$ ) impregnated with a mixture of $8 \%$ ethanol-oxalic acid and eluted with $\mathrm{CHCl}_{3}: \mathrm{MeOH} 9: 1$ to obtain red needles (4 mg) with m.p. 216-220 ${ }^{\circ} \mathrm{C}$; UV $\lambda \max \left(\mathrm{CHCl}_{3}\right): 246,280,312,440$; ${ }^{1} \mathrm{H}$ NMR $\left(\mathrm{CDCl}_{3}, 300 \mathrm{MHz}\right): \delta 8.876(\mathrm{~d}, \mathrm{~J}=5.1 \mathrm{~Hz}, 1 \mathrm{H}), \delta 8.55(\mathrm{dd}, \mathrm{J}=7.5,1.2 \mathrm{~Hz}, 1 \mathrm{H}), \delta$ 
$8.53(\mathrm{~d}, \mathrm{~J}=7.8 \mathrm{~Hz}, 1 \mathrm{H}), \delta 8.131(\mathrm{~d}, \mathrm{~J}=5.1 \mathrm{~Hz}, 1 \mathrm{H}), \delta 7.71(\mathrm{dt}, \mathrm{J}=7.5,1.2 \mathrm{~Hz}, 1 \mathrm{H}), \delta 7.49(\mathrm{dt}$, $\mathrm{J}=8.2,1.0 \mathrm{~Hz}, 1 \mathrm{H}), \delta 6.28(\mathrm{~s}, 2 \mathrm{H})$ and $\delta 4.258(\mathrm{~s}, 3 \mathrm{H})$.

The reference alkaloid for lysicamine was provided by Dr Diego Cortes (Universidad de Valencia, España) and used for quantification of lysicamine in seedlings.

\subsection{Quantification of aporphine alkaloids using high-performance liquid chromatography analysis}

Liriodenine, lysicamine and atherospermidine were quantified by liquid chromatography using a high-performance liquid chromatography system (Perkin Elmer® HPLC-UV/Vis, Series NCI 900) and a Spheri-5 amino reverse phase column (Perkin Elmer®, $100 \times 4.6 \mathrm{~mm} ; 5-\mu \mathrm{m}$ particle diameter). The mobile phase consisted of chloroform/methanol (96:4, isocratic), and the flow rate was $0.3 \mathrm{~mL} \cdot \mathrm{min}^{-1}$; the column temperature was maintained at $30^{\circ} \mathrm{C}$. UV detection was conducted at $300 \mathrm{~nm}$. The absorption spectra were obtained using a spectrophotometer (Thermo Electron Corporation ${ }^{\circledR}$ model Genesys $\left.10 \mathrm{UV}\right)$. The aporphine alkaloid reference samples in this system had retention times of $3.5 \pm 0.1 ; 4.0 \pm 0.2$ and $4.7 \pm 1.0 \mathrm{~mL} \mathrm{~min}^{-1}$ for atherospermidine, lysicamine and liriodenine, respectively. Alkaloid calibration curves were constructed by analysing stock solutions containing $1000,875,750,625,500,250,125,62.5,31.3,15.6$, 7.8 and $3.9 \mu \mathrm{g} . \mathrm{mL}^{-1}$ using the Turbochrom Work station (Perkin Elmer). Atherospermidine, lysicamine and liriodenine curves were linear in this area, with r2 values of 0.94, 0.97 and 0.99, respectively. The alkaloid organ extracts (roots, stems and leaves) were dissolved at a concentration of $1 \mathrm{mg} \cdot \mathrm{mL}^{-1}$, and then $20 \mu \mathrm{L}$ of each solution was analysed using highperformance liquid chromatography. The alkaloid contents were quantified by converting

high-performance liquid chromatography data to numbers of molecules using the following equations:

(g Alkaloid/FW Alkaloid)(Avogadro constant/Developmental time)

\subsection{Statistical analysis}

The effect of nitrogen on total alkaloids was analysed as the sum of average content of the three aporphine alkaloids in roots, stems and leaves at each time period. Then, an ANOVA (Tukey-HSD test, $\mathrm{P}<0.05$ ) was conducted. The average content of the aporphine 
alkaloids ( $\mathrm{n}=3$ ) were subjected to an ANOVA (Tukey-HSD test, $\mathrm{P}<0.05)$ to determine the effect of nitrogen in various plant organs and their diurnal variation. In addition, a correlation analysis was performed to determine the relationship between aporphine alkaloid content in plants organs, nitrogen treatments and alkaloids variation during the diurnal period. Statgraphics Centurion XV was used for the analyses. 


\section{References}

De la Cruz Chacón I, González-Esquinca AR. 2012. Liriodenine alkaloid in Annona diversifolia during early development. Nat Prod Res. 26:42-49.

Ministerio de Agricultura. 1976. Reglas Internacionales para Ensayos de Semillas. Instituto Nacional de Semillas y plantas de vivero. Dirección General de la Producción Agraria, reimpreso por la SARH, México.

Murashige T, Skoog F. 1962. A revised medium for rapid growth and bioassays with tobacco tissue cultures. Physiol Plant.15:473-497. 
Table S1. Salt composition of the nutrient solutions used for nitrogen treatment test.

Figure S1. Total alkaloid content during the day in Annona diversifolia Saff. with different nitrogen supply.

Figure S2. Nitrogen treatments effect on liriodenine in Annona diversifolia organs during the day.

Figure S3. Nitrogen treatments effect on lysicamine content in Annona diversifolia organs during the day.

Figure S4. Nitrogen treatments effect on atherospermidine content in Annona diversifolia organs during the day. 


\section{Supplementary Tables}

Table S1. Salt composition of the nutrient solutions and modified solutions used for nitrogen treatment test.

\begin{tabular}{|c|c|c|c|}
\hline & & Treatment & \\
\hline Salts & $60 \mathrm{Mm} \mathrm{N}^{\mathrm{a}}$ & $30 \mathrm{mMN}^{\mathrm{b}}$ & $0 \mathrm{mMN}^{\mathrm{c}}$ \\
\hline $\mathrm{NH}_{4} \mathrm{NO}_{3}$ & 1650 & $\overline{816}$ & - \\
\hline $\mathrm{KNO}_{3}$ & 1900 & 971 & - \\
\hline $\mathrm{KOH}$ & - & 515 & 1054 \\
\hline $\mathrm{CaCl}_{2} \cdot 2 \mathrm{H}_{2} \mathrm{O}$ & 440 & 440 & 440 \\
\hline $\mathrm{MgSO}_{4} \cdot 7 \mathrm{H}_{2} \mathrm{O}$ & 370 & 370 & 370 \\
\hline $\mathrm{KH}_{2} \mathrm{PO}_{4}$ & 170 & 170 & 170 \\
\hline $\mathrm{FeSO}_{4} \cdot 7 \mathrm{H}_{2} \mathrm{O}$ & 27.8 & 27.8 & 27.8 \\
\hline Na.EDTA & 37.3 & 37.3 & 37.3 \\
\hline $\mathrm{MnSO}_{4} \cdot \mathrm{H}_{2} \mathrm{O}$ & 16.9 & 16.9 & 16.9 \\
\hline $\mathrm{ZnSO}_{4} \cdot 7 \mathrm{H}_{2} \mathrm{O}$ & 8.6 & 8.6 & 8.6 \\
\hline KI & 0.83 & 0.83 & 0.83 \\
\hline $\mathrm{CuSO}_{4} \cdot 5 \mathrm{H}_{2} \mathrm{O}$ & 0.025 & 0.025 & 0.025 \\
\hline $\mathrm{CoCl}_{2} \cdot 6 \mathrm{H}_{2} \mathrm{O}$ & 0.025 & 0.025 & 0.025 \\
\hline $\mathrm{H}_{3} \mathrm{BO}_{3}$ & 6.2 & 6.2 & 6.2 \\
\hline $\mathrm{NaMoO}_{4} \cdot \mathrm{H}_{2} \mathrm{O}$ & 0.25 & 0.25 & 0.25 \\
\hline
\end{tabular}

Note: Values represent the salt concentration (ppm). ${ }^{a}$ High nitrogen level using Murashige and Skoog solution for reference. ${ }^{b}$ Moderate nitrogen level using Murashige and Skoog media modified. 'Zero nitrogen level using Murashige and Skoog media modified. 
Supplementary Figures

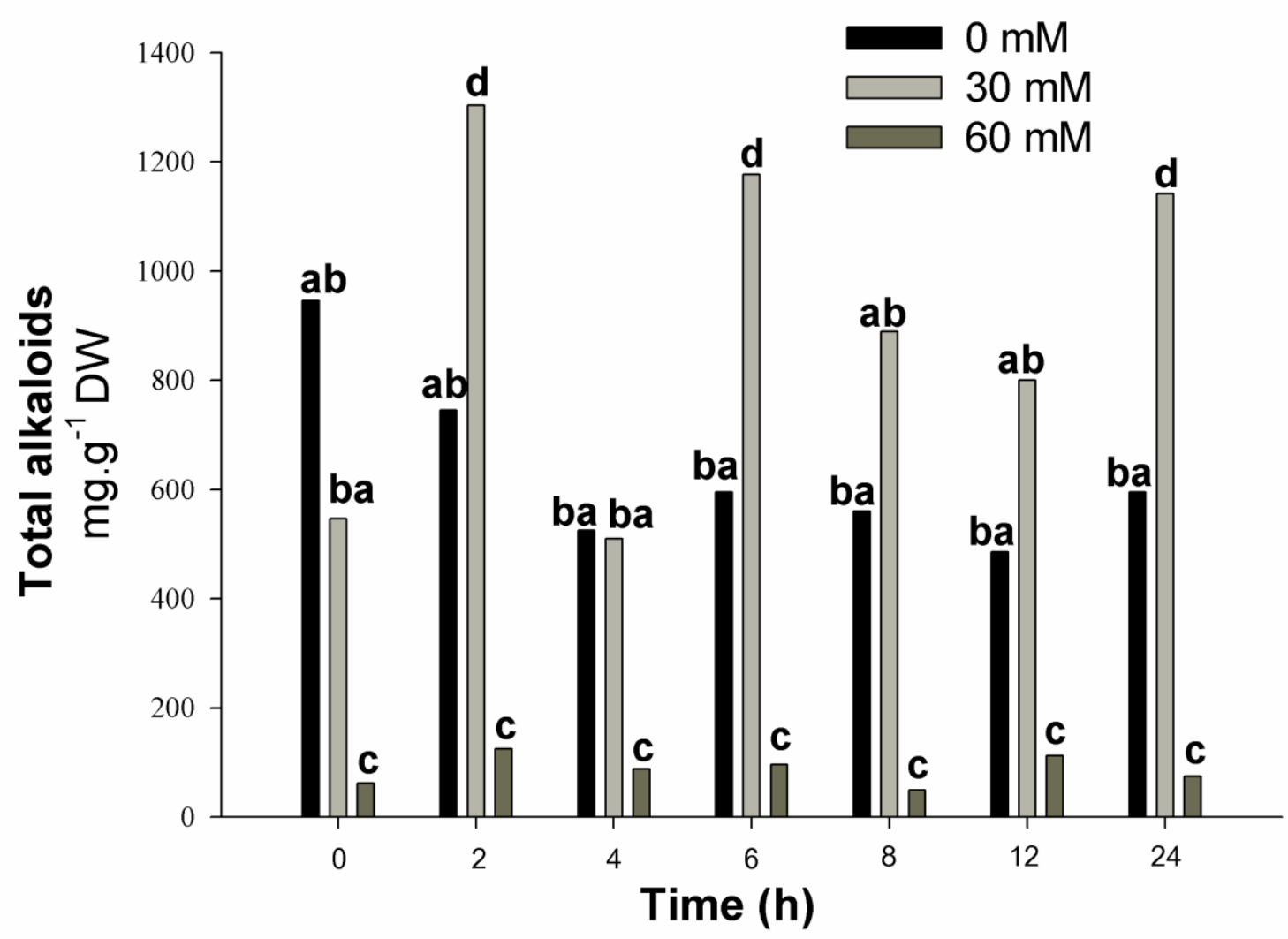

Figure S1. Total alkaloid content during the day in Annona diversifolia Saff. with different nitrogen supply. 

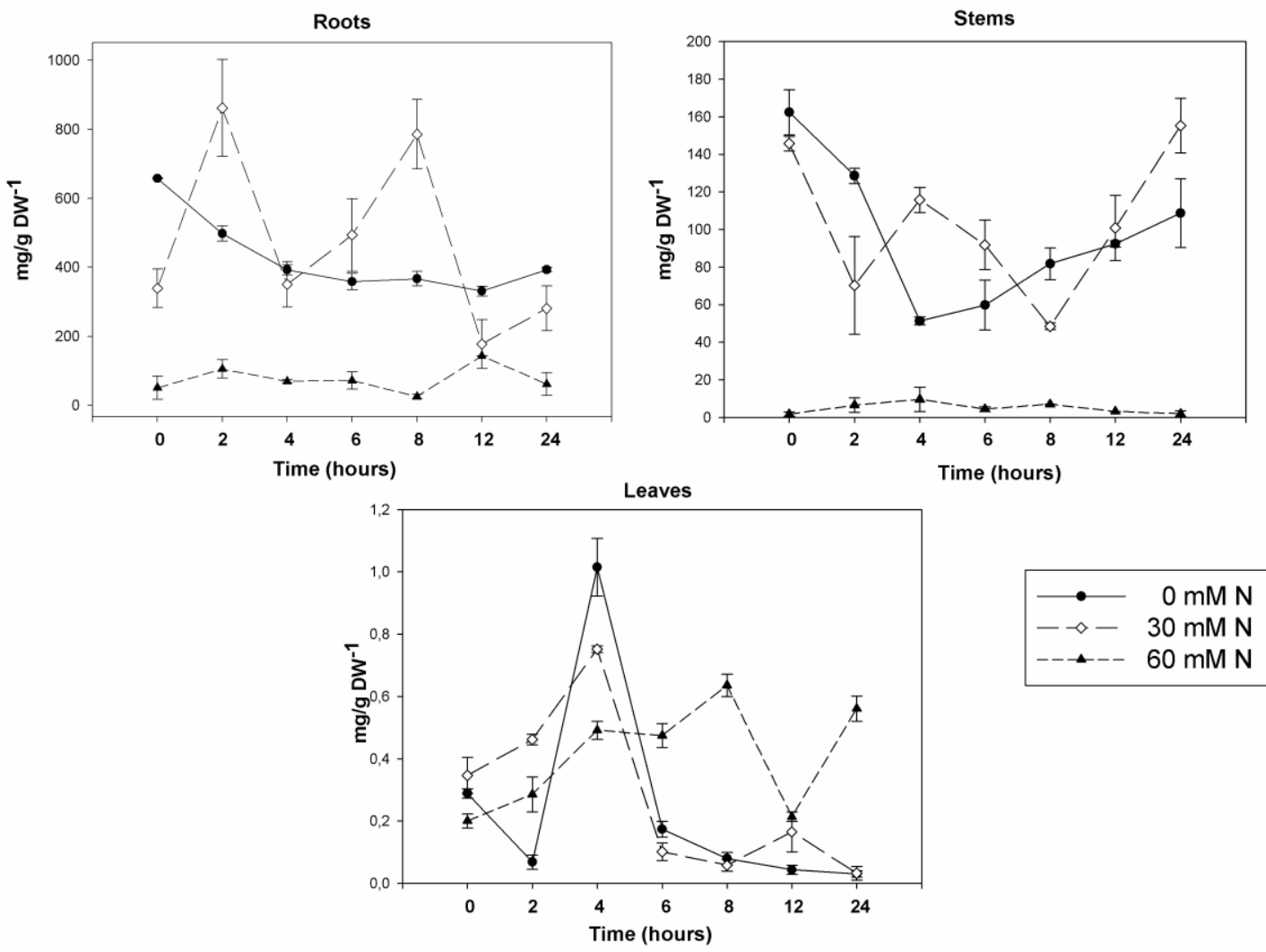

Figure S2. Nitrogen treatments effect on liriodenine in Annona diversifolia organs during the day. 

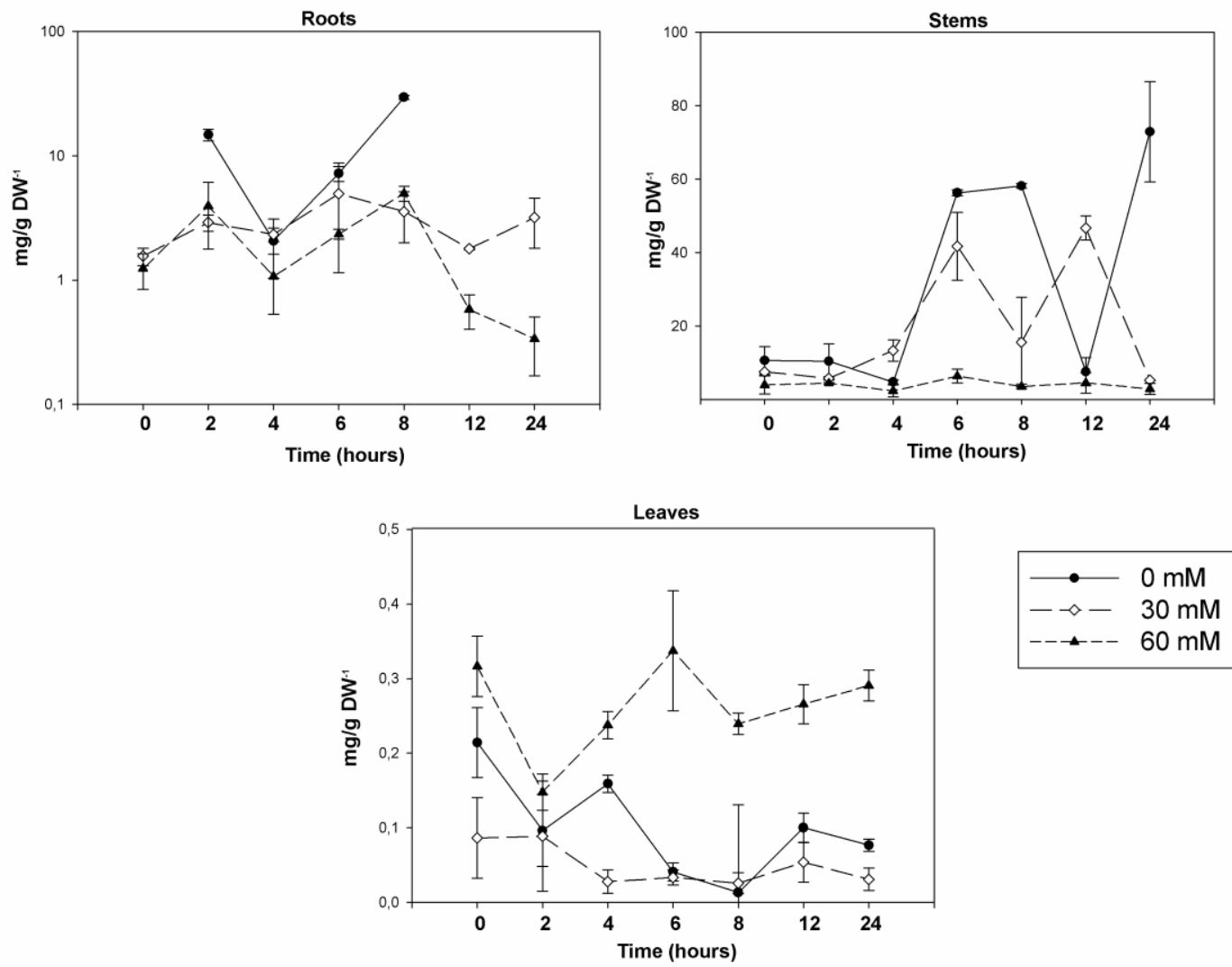

Figure S3. Nitrogen treatments effect on lysicamine content in Annona diversifolia organs during the day. 

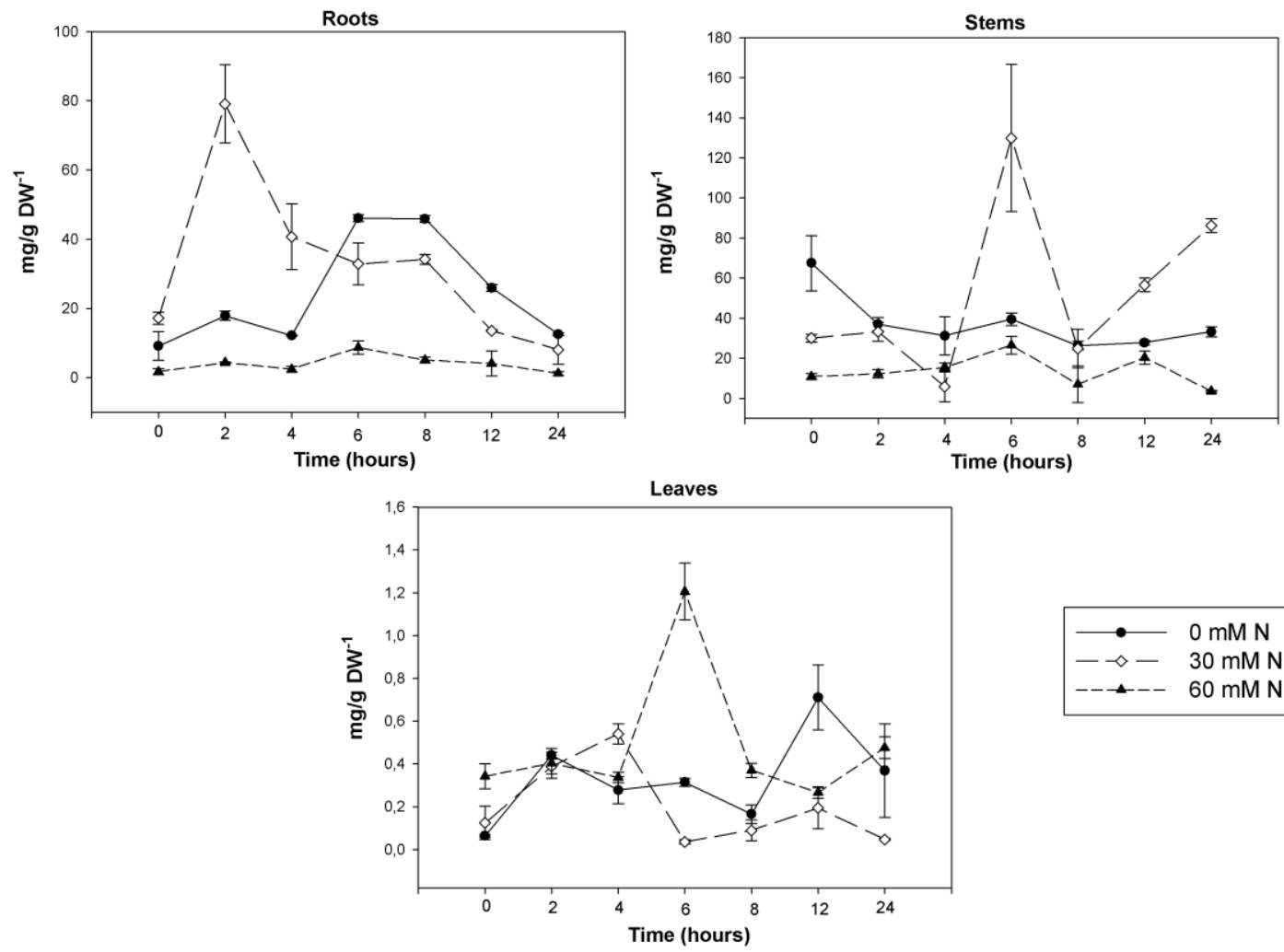

Figure S4. Nitrogen treatments effect on atherospermidine content in Annona diversifolia organs during the day. 